\title{
The tribe Hippomaneae (Euphorbiaceae) in Brazil
}

\author{
A tribo Hippomaneae (Euphorbiaceae) no Brasil
}

\author{
Hans-Joachim Esser $^{1}$
}

\begin{abstract}
The tribe Hippomaneae (Euphorbiaceae) in Brazil. The tribe Hippomaneae is discussed with respect to its taxonomic history, its placement within the Euphorbiaceae, its diagnostic characters (particularly the floral buds), current data on phylogeny and subdivision, and its general pattern of diversity. The tribe is represented in Brazil with 13 genera and ca. 120 species. A key to the Brazilian genera is provided. All Brazilian genera are discussed, citing relevant characters, recent taxonomic literature, and the current state of knowledge, sometimes pointing to unresolved problems. For five of the genera, published revisions exist; six genera have unpublished but completed revisions or are currently under revision. Actinostemon and Gymnanthes are currently the most difficult genera, mostly based on the absence of available up-to-date taxonomic references. For Mabea and Senefeldera, two genera with completed but currently unpublished revisions, additional data are given on aspects of their taxonomy, ecology and biogeography.
\end{abstract}

Key words: Brazilian Hippomaneae, Mabea, Senefeldera, flowering plant taxonomy.

\section{Resumo}

A tribo Hippomaneae é discutida em relação à sua história taxonômica, posição sistemática nas Euphorbiaceae, em seus principais caracteres morfológicos diagnósticos, com ênfase no botão floral, em sua atual filogenia e subdivisão, e em seus padrões gerais de diversidade. A tribo está representada no Brasil por 13 gêneros e cerca de 120 espécies. Uma chave para os gêneros brasileiros é fornecida. Todos os gêneros do Brasil são discutidos sucintamente, citando-se suas características mais relevantes, a literatura taxonômica mais recente e o seu estado atual de conhecimento, bem como algumas sugestões para problemas ainda não resolvidos sobre os táxons. Há revisões publicadas para cinco dos gêneros, sendo que seis já foram revisados ou estão sendo revisados, mas permanecem inéditos. Actinostemon e Gymnanthes são atualmente os gêneros mais difíceis, especialmente pela ausência de referências taxonômicas atuais disponíveis. Para Mabea e Senefeldera, gêneros já revisados, mas não publicados, são fornecidos dados adicionais sobre a taxonomia, ecologia e biogeografia.

Palavras-chave: Hippomaneae no Brasil, Mabea, Senefeldera, taxonomia de Fanerógamos.

\section{Introduction}

The Euphorbiaceae are one of the very large plant families and include mostly tropical, predominantly woody plants. Recent molecular studies led to a change in the circumscription of the family by moving several of the former subfamilies into separate families, e.g. Phyllanthaceae and Picrodendraceae (Wurdack et al. 2005; APG III 2009). The remaining Euphorbiaceae s.str. still include the largest part of the traditional family, with ca. 230 genera and ca. 6,000 species, and are usually characterized by the typical 3-locular, superior, dehiscent fruits with one seed per locule, and small unisexual flowers in monoecious (rarely dioecious) inflorescences.
Euphorbiaceae are still comparatively poorly studied, despite their notable economic importance, possible pharmaceutical uses, and general abundance. One of the reasons for this may be their small, inconspicuous flowers, which may however been grouped into large, attractive inflorescences.

Within Euphorbiaceae, the subfamily Euphorbioideae unites most of the species with white latex and is characterized by, amongst others, non-articulated laticifers and the flowers without a disc or petals (Webster 1994; Radcliffe-Smith 2001). The subfamily is also supported by molecular phylogenies (Wurdack et al. 2005).

Euphorbioideae consist of two large tribes, in addition to several more isolated genera that have 
been assigned to smaller tribes. One of these two large tribes are the Euphorbieae, which includes mainly the large genus Euphorbia L., as well as four other smaller genera. Euphorbia is one of the largest genera of flowering plants with over 2,000 species, including the former segregate genera Pedilanthus Neck. ex Poit., Chamaesyce Gray, Monadenium Pax, and others. (Steinmann \& Porter 2002; Bruyns et al. 2006) The genus now includes all species characterized by the presence of the cyathium, a unique pseudanthium composed of flowers reduced to a single stamen or ovary, and surrounded by fused bracts with a ring of extrafloral nectaries; it is currently being studied by an international network of researchers funded by the PBI (Planetary Biodiversity Inventories) program of the National Science Foundation (Esser et al. 2009; Riina \& Berry 2011).

The second large tribe of Euphorbioideae are the Hippomaneae A.Juss. ex Bartl. The Hippomaneae are pantropical (with only few extratropical species), and comprise 33 genera and ca. 300 species of mostly woody plants (with few herbs and succulents). Since its first description by Jussieu (1824), the tribe has been generally accepted, with only slight changes in circumscription. Jussieu (1824) had originally excluded Mabea Aubl., and on the other hand, Hura L. was included by several botanists up to Hurusawa (1954), who removed this genus from the tribe and placed it into a separate tribe, Hureae Dumort. The Hippomaneae were however treated under different names and at different ranks by various authors, e.g., as Stillingiidae by Baillon (1858), series Excoecarieae by Baillon (1874), subtribe Hippomaneae by Bentham \& Hooker (1880), or even as a separate family Hippomanaceae by Agardh (1858). Bentham (1878) even stated that it is one of the most natural subtribes of his "Crotoneae".

An overview of Hippomaneae will be presented below as a contribution to a better understanding of it in particular in Brazil.

\section{The Morphology of Hippomaneae}

Hippomaneae lack petals and a disc, and similarly they have no staminodes or pistillodes in their flowers, but these characters are shared with other Euphorbiaceae such as the Euphorbieae. In contrast to the Euphorbieae, the stigmas are always undivided, with the exception of few species of Homalanthus A.Juss. that have bifid stigmas. Hippomaneae are characterized by their elongate thyrsoid inflorescences, with pistillate flowers at the base, one per bract, and numerous staminate cymules apically, with one or several flowers per bract, and by their very typical floral buds. The flowers of both sexes have a small calyx, which leaves parts of the sexual organs exposed; immature flowers are inclinate, initially appressed to the inflorescence axis, and then are covered by the floral bracts which are conspicuously large and often glandular. In inflorescence buds, only the spirally arranged, imbricate bracts are visible outside. This type of inflorescence buds is quite unique in Euphorbiaceae, and is quite probably apomorphic for the tribe. In Rhodothyrsus Esser this is even obvious in mature inflorescences, with only few single flowers spreading upright at a given time, the majority of flowers still appressed into cavities of the central axis (Esser 1999c). Actinostemon Mart. ex Klotzsch is an exception because there the flower buds are protected by sterile bud scales, rather than by floral bracts. The Hippomaneae are therefore characterized by the combination of bud protection by bracts, inclinate flowers, and and a small calyx that does not have primary protective function anymore; these characters are obviously functionally correlated.

This syndrome was described and illustrated in more detail by Esser (1994) and Esser et al. (1998); Esser et al. (1998) and Esser (2001) used it for the circumscription of the tribe. Balakrishnan \& Chakrabarty (2007) even considered it of such importance that they proposed a separate subfamily for the tribe, Euphorbiaceae subfam. Hippomanioideae Chakrab. \& N.P.Balakr.

Bud morphology is usually not described for genera or higher taxa in the literature. In other tribes of Euphorbiaceae, immature flowers are usually erect, and the calyx completely encloses the sexual organs, whereas the floral bracts are small to nearly absent (e.g., in Croton L.). In Euphorbioideae, the mature inflorescences of tribes Pachystromateae (Pax \& K.Hoffm.) Pax and Hureae Dumort. appear very similar to those of Hippomaneae. In Hura, however, the flowers are erect in bud and covered by a tunica, which is formed by the fused bracts so that the immature flowers are covered by the (transformed) bracts. In Pachystroma Müll.Arg., floral buds are erect, and the calyx completely encloses the sexual parts (Esser 2001). The cyathia of Euphorbia are hardly comparable in bud structure, but it should be noted that, despite a wealth of publications on the structure of the cyathium, the floral buds have hardly been discussed in detail. The much reduced original flowers are naked, with even the calyx reduced, so that other organs of the inflorescence must protect young flowers, 
usually the bracts of the cyathial cup. Therefore, it appears likely that the characteristic bud syndrome might not be sufficient to establish the monophyly of Hippomaneae. Indeed, the molecular data of Wurdack et al. (2005) show that Hippomaneae are probably paraphyletic, with both Hureae and Pachystromateae embedded within them. The problem with the latter two tribes will be briefly discussed below. The status of Hippomaneae as a separate subfamily, as proposed by Balakrishnan \& Chakrabarty (2007), is clearly not justified.

\section{Taxonomy and Relationships}

Aside from the issues of the circumscription of the tribe Hippomaneae, many of the generic distinctions have been long known to be "uncertain and controversial" (Webster 1994). These difficulties were probably caused by a strong focus on floral characters. The staminate flowers of the tribe are much reduced, even more so than in many other Euphorbiaceae, and presumably show homoplasy in several of the few differential characters. Esser (1994, 1999b, 2001; Esser et al. 1998, 2010) showed that the Hippomaneae are quite rich in useful and reliable characters of architecture, leaves, fruits and seeds, which are in most cases more important than floral characters, showing less homoplasy and with a larger number of characters.

A first morphological phylogeny of Hippomaneae was published by Kruijt (1996), restricted to few genera but supporting the rearrangement of the previously unnatural Sapium Jacq. and its allies into several distinct genera.

Esser (2001) proposed a new overall generic classification of the Hippomaneae. It was based on a worldwide morphological survey of members of all genera and sections of the tribe as well as unusual species in a phylogenetic context, with emphasis on character states presumably apomorphic on a global scale. The approach was applied in detail for tropical Southeast Asia (Esser et al. 1998; Welzen \& Esser 1998; Esser 1999b), through a morphological cladistic study of selected species of all Malesian genera; but it also included the type species of several Neotropical genera for nomenclatural reasons, in order to achieve an improved placement of all relevant (Malesian) species. Esser (2001) accepted only genera in his proposed new classification that are characterized by morphological apomorphies on a global scale, and therefore monophyletic with a sufficient confidence as can be deducted from morphological characters; it was later followed up by
Esser et al. (2010). Wurdack et al. (2005) conducted a molecular phylogenetic study based on several genes, including several but not all genera of the Hippomaneae. Their results largely supported the morphological system of Esser (2001) with regard to the presumable monophyly of most (although not all) genera sampled.

The Hippomaneae do not include any single, large genera, but rather a larger number of smaller genera, several of them monotypic. The largest genus is Mabea with slightly over $40 \mathrm{spp}$. (Esser 1994, 2000, 2001). Sapium had been considered a genus of nearly 100 species in the past (Pax \& Hoffmann 1912; Webster 1994), but Kruijt (1996) established a large number of new synonyms for the neotropical species; additionally, all names of paleotropical species have recently been excluded from Sapium by Kruijt (1996) and Esser (1999b, 2002), so that the actual number of currently accepted species is around 20 only. Likewise, Sebastiania Spreng. is now much smaller than was circumscribed by Pax \& Hoffmann (1912) and Webster (1994), because of new synonymies and because of the subdivision of the former large genus into several distinct genera (see below).

Most genera are probably circumscribed as monophyletic now. Few genera are probably still not monophyletic in their current concept, with the Brazilian ones discussed below. One new genus is still undescribed from Peru (Esser, ined.). A number of species still need to be described from the Andean countries and Madagascar, but only very few from Brazil (see below). New combinations are however still required for a number of Brazilian taxa, but many of these pertain to genera in need of revision and therefore have not been proposed yet. The taxonomy at the species level has been updated and revised by the recently published World Checklist of Euphorbiaceae; for the Hippomaneae, parts of the content there were contributed by Esser (2000) and Govaerts et al. (2000). But entries there in particular for Gymnanthes Sw. and Sebastiania are not completely correct.

The last complete monograph of the Euphorbiaceae was published by Müller (1866). For the ambitious project of the "Pflanzenreich" of Engler and his students of the early $20^{\text {th }}$ century, the Euphorbiaceae could unfortunately never be finished, but the part on the Hippomanae was published by Pax \& Hoffmann (1912). This is the last complete revision of the tribe, although of course outdated in many parts now, and executed with a very narrow species concept. 
Pax \& Hoffmann subdivided the Hippomaneae into nine subtribes. Three of these were later excluded from the tribe (Hurinae Pax \& K.Hoffm., Omphaleinae Pax \& K.Hoffm., Trisyngyninae Pax \& K.Hoffm. - the latter two are even excluded from the Euphorbioideae now), three others were clearly artificial and therefore not accepted by later authors. Webster (1994) accepted only three of these subtribes, the Carumbiinae Müll.Arg. (= Homalanthinae Pax \& K.Hoffm.), Mabeinae Pax \& K.Hoffm., and Hippomaninae (= Stillingiinae Pax \& K.Hoffm., nom. inval.). The Carumbiinae include only a single paleotropical genus, Homalanthus A.Juss.; the genus is aberrant in several characters, such as large terminal stipules, stigmas with large apical nectar glands and sometimes bifid, and strongly zygomorphic staminate flowers with a flattened calyx. According to Esser et al. (1998), Homalanthus seems to be sister to the remaining (mostly Asian) Hippomaneae, so that this subtribe was still accepted by Esser (2001). This is, however, not obvious from the results of Wurdack et al. (2005), where Homalanthus is embedded in the "regular" Hippomaneae. The Mabeinae (as a then unnamed grouping) were defined by the enlarged, convex-conical receptacle of the staminate flowers by Müller (1866), including the neotropical Mabea and Senefeldera Mart. as well as Conosapium Müll. Arg. from Madagascar. Bentham \& Hooker (1880) added the character of an increased stamen number (which is correlated with the convex receptacle for spatial reasons). Webster (1994) added the character of compound thyrses, and accepted the subtribe with three neotropical genera (Mabea, Senefeldera, Senefelderopsis Steyerm.). These three genera do not have many characters in common and are not closely related to each other; Senefeldera sensu Webster included three separate genera, as discussed below, and Senefelderopsis does not even have a higher stamen number; other genera with sometimes compound thyrses and sometimes numerous stamens (e.g., Gymnanthes) were not included. Although a complete phylogeny of the Hippomaneae is still lacking, the Mabeinae should be abandoned as being clearly polyphyletic. The subtribe was synonymized by Esser $(1994,2001)$ with the Hippomaninae.
Wurdack et al. (2005) discussed the Hippomaneae (together with Hureae and Pachystromateae) as non-pseudanthial Euphorbioideae. In their molecular phylogenetic study they found a bifurcation into two clades of roughly equal size (called $\mathrm{H} 1$ and $\mathrm{H} 2$ ). Their subdivision is partly supported by morphological characters: clade $\mathrm{H} 2$ includes all genera with basically sessile flowers with free sepals and fruits with 3 or more vascular strands per septum (such as Excoecaria L. and Sebastiania, discussed below), and H1 the majority of genera with pedicellate flowers and fused sepals and fruits with one vascular strand per septum (such as Mabea and Gymnanthes). But some genera that appear closely related to genera of $\mathrm{H} 1$ from morphology are placed in H2, such as the pair of Senefelderopsis (H1) and Sapium and Stillingia Garden ex L. (H2). Therefore H1 and H2, in the exact circumscription of Wurdack et al. (2005), are not supported by morphological characters, but the final system will certainly be similar. At this moment the Hippomaneae should preferably not be subdivided further.

\section{Distribution and Ecology}

The generic distribution of the Hippomaneae on the different continents and important biogeographical regions is summarized in Table 1. The tribe is represented by a moderate number of genera in tropical and subtropical Asia. In Australia there are only three genera, with less than 10 species. On mainland Africa the diversity is also quite low, whereas on Madagascar, the species diversity is higher with ca. 18 species (V. Malecot, pers. comm.). Most genera are restricted to the New World, and Brazil is the country with the largest number of genera, although no genus is endemic there.

Five genera have an amphiatlantic distribution; of these, Maprounea Aubl. and possibly Excoecaria / Sebastiania (if these two are synonymous) have a comparable diversity in both the Old and New World, the others (Gymnanthes, Microstachys A.Juss., Stillingia) are mostly neotropical with one of very few species only in the paleotropics.

Table 1 - Distribution of genera of Hippomaneae on the continents and in Brazil; number of endemic genera in brackets.

\begin{tabular}{cccccccc}
\hline worldwide & Brazil & Neotropics & USA/ Mexico & mainland Africa & Madagascar & Asia & Australia \\
\hline 33 & $13(0)$ & $21(14)$ & $5(1)$ & $8(1)$ & $5(2)$ & $10(4)$ & $3(0)$ \\
\hline
\end{tabular}




\section{Hippomaneae, Hureae and Pachystromateae}

The two tribes of Hureae Dumort. and Pachystromateae (Pax \& K.Hoffm.) Pax are, according to Wurdack et al. (2005), embedded in Hippomaneae. The three can be separated by morphological characters: Hippomaneae by usually glandular floral bracts, inclinate flowers with a small calyx open in bud; Hureae by eglandular floral bracts, peltate or adnate to the inflorescence axis, covering the floral buds but transformed, and erect flowers; and Pachystromateae by glandular floral bracts, erect floral buds and a large calyx closed in bud. Although suggested by the results of Wurdack et al. (2005), the tribes have not been united at this moment, and will not be done so here. When Dumortier (1829) described the Hureae, he included Hippomane L. into it, the type of Hippomaneae. Therefore, Hureae (1829) have priority over Hippomaneae (1830), and after merging the enlarged tribe would have to be named Hureae. The name of Hippomaneae is therefore used in a restricted (although presumably paraphyletic) sense here. Pachystroma Müll. Arg. (monotypic) and Hureae (four genera with 17 species in Brazil) are not considered here.

\section{The Hippomaneae in Brazil}

In Brazil, the Hippomaneae include 13 genera, with approximately 120 species. A key to these genera is provided here, based on the global key of Esser (2001).

\section{Key to the genera of Hippomaneae in Brazil}

1. Leaves with distinct glands on lamina base or petiole apex visible from above.

2. Leaves entire, basically alternate but often subverticillate to crowded; inflorescence compound thyrses; staminate cymules 3-flowered, the flowers with 6-13 stamens. Senefeldera

2'. Leaves serrate to subentire, alternate; inflorescence simple; staminate cymules many-flowered, the flowers with 2 stamens.

3. Glands on the upper base of the lamina; seeds dry, without aril; basal part of fruits woody, remaining on the plant as a woody carpidiophore Stillingia

3'. Glands on the petiole apex, rarely on the lamina base; seeds with a reddish aril; basal part of fruit inconspicuous, not woody Sapium

1'. Leaves without distinct glands on lamina base or petiole apex visible from above.

4. Herbs to subshrubs; leaves closely glandular-serrate (teeth less than $0.5 \mathrm{~mm}$ apart) or entire; inflorescences often leaf-opposed; ovaries and fruits often with rows of multiple spines, rarely smooth Microstachys

4'. Shrubs, trees or lianas; leaves more distantly serrate (teeth $0.5-5 \mathrm{~mm}$ apart) or entire; inflorescences never leaf-opposed; ovaries and fruits smooth or with pairs of solitary appendages.

5. Flower buds covered by numerous sterile bud scales, the floral bracts being reduced and weak to even absent. Actinostemon

5'. Flower buds covered by the larger and often glandular floral bracts, one per node, or rarely by a single scaly bract, but not by numerous sterile scales.

6. Inflorescences and infructescences compound thyrses.

7. Hairs both simple and malpighiaceous-dibrachiate; leaf lamina never glaucous below; glands on the lamina below close to the midrib (laminar); inflorescence purplish-red; seed surface sculptured Rhodothyrsus

7'. Hairs simple/or dendritic, never malpighiaceous-dibrachiate; glands on the lamina below close to or even on the margin (marginal) (if, very rarely, glands laminar, then leaf lamina glaucous below); inflorescence yellowish-green to reddish; seed surface smooth, not sculptured.

8. Hairs dendritic (very rarely unbranched on single plants); ovaries and young fruits distinctly pubescent.

9. Glands of the floral bracts cup- to disc-shaped; staminate flowers with 2 fused stamens; fruits glabrescent. Dendrothrix 
9'. Glands of the floral bracts ellipsoid or (rarely) absent; staminate flowers with 3-100 free stamens; fruits persistently tomentose Mabea

8'. Hairs unbranched or absent; ovaries and young fruits glabrous or sparsely hairy.

10. Leaves subverticillate to crowded; glands on the lamina below remote from the margin (laminar); lateral inflorescence branches initially covered by a single large scaly bract; staminate flowers strongly zygomorphic-inclinate even when mature; seeds with dorsal chalaza Pseudosenefeldera

10'. Leaves regularly alternate; glands on the lamina below close to or on the margin (marginal) (if, very rarely, glands laminar, then leaf lamina glaucous below); lateral inflorescence branches never covered by a single large scaly bract; staminate flowers hardly zygomorphic or inclinate when mature; seeds with basal chalaza

Gymnanthes

6'. Inflorescences and infructescences unbranched thyrses.

11. Hairs dendritic; ovaries and fruits densely tomentose; pistillate flowers with (3-)6(-9) sepals ... Mabea

11'. Hairs unbranched or absent; ovaries and fruits glabrous to sparsely pubescent; pistillate flowers with 3 sepals

12. Leaves long-pedicellate (compared to lamina), entire, their glands below only in the basal part and close to the midrib; staminate flowers congested into a glomerulate head, the pistillate flowers long-pedicellate and separated; upper part of seeds covered by a large caruncle .....

Maprounea

12'. Leaves short-pedicellate (compared to lamina), entire to serrate, their glands also or mostly in the apical part and close to or on the margin; inflorescence elongate, staminate flowers not congested into a glomerulate head, the pistillate flowers not conspicuously separated; caruncle of seeds absent or small but not covering the upper part of the seeds.

13. Staminate cymules many-flowered, the flowers with 2 stamens each.

14. Plants often succulent; seeds dry, without aril; basal part of fruits woody, remaining on the plant as a woody carpidiophore Stillingia

14'. Plants never succulent; seeds with reddish aril; basal part of fruit inconspicuous, not woody Sapium

13'. Staminate cymules with 3-many flowers, the flowers with 3 or more stamens each.

15. Leaves with a pair of conspicuously enlarged glands at the lower lamina base but not visible from above; staminate cymules with numerous $(>5)$ flowers

Pleradenophora

15 '. Leaves without conspicuously enlarged glands at the lower lamina base; staminate cymules with 1 or 3 flowers.

16. Plants glabrous; staminate flowers quite sessile, their sepals distinct, free; fruits with a thin pericarp $(<1 / 10$ of length); septa with 3 or more vascular strands

Sebastiania

16'. Plants glabrous or pubescent; staminate flowers pedicellate (rarely subsessile), the sepals fused or, if free, reduced to nearly absent; fruits with a thick pericarp (ca. 1/10 of length); septa with 1 vascular strand. Gymnanthes

In the following, the Brazilian genera are discussed briefly. The sequence follows Esser (2001), representing tentative relationships. A species checklist cannot be given yet for several of the genera; for other genera the list of Brazilian species can be deducted from recent publications, cited below, and which are still valid. For Mabea and Senefeldera additional, previously unpublished information is given, that could be useful here.

\section{Sebastiania Spreng.}

Sebastiania was conceived in very wide sense by Pax \& Hoffmann (1912) and Webster (1994), then including ca. 100 species. Webster had already noted that this might not be a natural concept. Pax \& Hoffmann had united numerous species here with the single common character of three stamens in staminate flowers. Esser (1994, 2001; Esser et al. 2010) showed that the different 
sections of Sebastiania sensu Pax \& Hoffmann differ in numerous important characters, whereas other species with also three stamens had not been included at all, e.g., Senefelderopsis (of course not yet known to Pax \& Hoffman) and several paleotropical sections and genera (several of them treated under Sapium by them). Esser restricted Sebastiania to its type section "Eusebastiania Müll.Arg.". This was also corroborated by the morphological phylogeny of Esser et al. (1998), as well as by the molecular data of Wurdack et al. (2005).

Sebastiania in this restricted sense is easy to recognize in Brazil by being completely glabrous, the flowers (sub)sessile, the staminate ones with \pm free sepals and three free stamens, and the smooth fruits with a comparatively thin wall, dry mature mericarps, and the mericap septa with usually three vascular strands.

Sebastiania was revised in the excellent, but still unpublished, thesis of Melo (2005). According to him, the genus has ca. 20 species overall, with nine species occurring in Brazil. Although the genus is sufficiently well established in the Neotropics and cannot be confused with another genus there, a systematic problem remains, which is the distinction from Excoecaria. Excoecaria is a paleotropical genus of ca. 35 species, occurring from Africa through Asia to Australia, and it is extremely similar to Sebastiania. Both phylogenies of Esser et al. (1998) and Wurdack et al. (2005) showed that both genera together form a single clade, and could be united. In this case, Excoecaria Linnaeus (1753) would have priority over Sebastiania Sprengel (1821). Pax \& Hoffmann (1912) did not list any reliable distinction at all. Webster (1994) separated them by the absence or presence of a caruncle, and the monoecious vs. dioecious distribution of the sexes; the first of these characters does not distinguish them at all when only Sebastiania s.str. is considered; although is true that few species of Excoecaria are dioecious, this distinction does not hold when all species are considered - the majority of species of Excoecaria is monoecious too. Esser (2001) separated them by characters of the staminate bracts, which can perhaps not be maintained when all species have been critically revised. Leaves and fruits can probably not be distinguished either. Although it seems quite obvious that both genera should be united, this is not done here, before revisions of both become available.

\section{Microstachys A.Juss.}

Microstachys shares sessile staminate flowers with \pm free sepals and three free stamens with Sebastiania, which is why the two had been united previously. Microstachys has several unique characters in Hippomaneae, however, such as the herbaceous or subshrubby habit, the peculiar leaf margin with very small and dense glandular teeth (if not entire), the architecture with usually leafopposed staminate inflorescences, and the pistillate flowers separated along the stem, ovaries and fruit with rows of multiples spiny appendages, and seeds with a large and often stipitate disc-shaped caruncle. As Webster (1994) had suspected, and was confirmed by Esser et al. (1998), Esser (1998, 2001) and Wurdack et al. (2005), Microstachys is a very characteristic and monophyletic genus with a pantropical distribution. Brazil is its centre of diversity, with 11 of the total 15 known species growing there, four of them endemic (Esser 1998; Govaerts et al. 2000). A revision of the genus is currently being undertaken and two additional species have just been established (Silva \& Esser 2011). Microstachys has a couple of characteristic and well-defined species, many growing as local endemics in Bahia and Minas Gerais, and often distinguished by characters of the leaves, sometimes by the indumentum or the fruits, but rarely by floral characters. Two weedy species are widespread and highly variable, $M$. corniculata (Vahl) Griseb., occurring from Mexico to Paraguay, and M. hispida (Mart. \& Zucc.) Govaerts, mostly a Brazilian species but reaching Bolivia. Müller (1863) even failed to separate several of the species and united a considerable part of the genus into a $M$. polymorpha Müll.Arg., an illegitimate name. The distribution pattern in the Old World is comparable to the New World, with one very widespread taxon from Africa to Australia, M. chamaelea (L.) Müll. Arg., and three local endemics in Africa.

\section{Stillingia Garden ex L.}

Stillingia seems to be well characterized by the characteristic woody base of the fruit, which remains on the plant after dehiscence of the fruit and shedding of the seed as a three-horned carpidiophore. Stillingia is similar to Sapium in many characters, the staminate inflorescences with bistaminate flowers in many-flowered cymules are even hardly distinguishable, and the leaves usually differ from Sapium only by the absence of petiolar glands. The genus is mostly American, with only a single 
species paleotropical, S. lineata (Lam.) Müll.Arg., there often on beaches on islands (Esser 1999b). The American species were revised by Rogers (1951), with 23 species accepted; this last revision, however, was based on a low number of collections studied for South America, and is outdated in parts. Since then, five additional species have been recognized as new, mostly from Mexico and the Andean countries (e.g, McVaugh 1995; Belgrano \& Pozner 2005; Esser 2010), and one from Brazil, $S$. argutedentata Jablonski (1967b). The carpidiophore is a character that obviously developed several times within Euphorbiaceae, and can be found in a very similar way in, e.g., Adenopeltis Bertero ex A.Juss., a genus of Hippomaneae endemic to Chile, but with very different flowers. Therefore the carpidiophore may have developed more than once, and this is particularly true for Gymnostillingia Müll.Arg. from Mexico and the USA, often forming herbs or subshrubs, currently treated as a separate subgenus of Stillingia (Rogers 1951), and possibly separated from Stillingia s.str. also according to the data of Wurdack et al. (2005). The monophyly of the genus is therefore still uncertain.

In contrast to most other genera of Hippomaneae, most species of Stillingia are narrow endemics. According to current knowledge, the genus includes 28 species. The biogeography is quite interesting. The majority of species occur in Mexico and the USA. The South American species are either non-succulent shrubs of mostly Andean distribution, and are often very local endemics known from few valleys only, such as $S$. bodenbenderi (Kuntze) D.J.Rogers from Argentina, or S. peruviana D.J.Rogers from Peru; the geographical distances between the different taxa are often very large. Another group of species forms succulent shrubs in the dry parts of northeastern Brazil, also with restricted distributions. The species groups with distinct geographical patterns are usually morphologically separable too, and were grouped in two subgenera and several series by Rogers (1951). Six species are known from Brazil, all endemic to the country.

\section{Sapium Jacq.}

Pax \& Hoffmann (1912) applied a very wide and completely unnatural circumscription to Sapium. Although they could not cite a single relevant, reliable diagnostic character for their generic concept, Webster (1994) repeated their circumscription, but at the same time cited a character ("fleshy seed coat") which would not apply to a large part of the species included by him. Kruijt (1996) published a complete monograph of the Neotropical taxa of the genus, removing most paleotropical species from the genus (additional ones were removed later by Esser 1999b). As a result, Sapium is restricted now to 'subgenus Eusapium Pax \& K.Hoffm. sect. Americana Pax \& K.Hoffm.', an invalid name. This Sapium s.str. is very well characterized by the seeds with a red aril (unique in Hippomaneae, in particular absent from all taxa recently excluded), the fruits without a carpidiophore, and leaves with petiolar glands (these glands only being absent in Sapium marmieri Huber). Without fruits, Sapium and Stillingia can be very similar, in particular by their subsessile staminate flowers with two free stamens, although the differences in leaf glands still remain (Esser 2010). Both are maintained as separate genera; they are distinguishable well enough, at least Sapium clearly seems to be monophyletic (Kruijt 1996; Esser et al. 1998) and at least a core Stillingia will be monophyletic too. This concept guarantees nomenclatural stability, because for any other solution a large number of other genera of Hippomaneae would have to be considered too, e.g. Hippomane and paleotropical taxa, and numerous and probably unnecessary name changes would be needed.

Kruijt's excellent monograph was based on a large number of collections, and established the species-level taxonomy very well. From the 21 species accepted by Kruijt overall, 9 occur in Brazil, but only one of them ( $S$. sellowianum (Müll.Arg.) Huber) being endemic. Kruijt applied a wide species concept, uniting 52 synonyms under S. glandulosum (L.) Morong. He seems justified to do so; only in very few cases did he probably synonymize too many names. One of these was discussed by Esser (1999d) for Venezuela, who suggested to re-separate the plants with 2-locular ovaries and fruits ( $S$. contortum Croizat in Venezuela; similar plants in western Amazonia were described as S. pavonianum (Müll.Arg.) Huber). Sapium is the only South-American genus of Hippomaneae in which the locule number can be a taxonomically relevant character.

\section{Dendrothrix Esser}

The genus was described and discussed by Esser (1993a), which was also a complete revision. It is well characterized by reddish-brownish dendritic hairs (the only example in Hippomaneae besides 
Mabea), unusual nectar glands in small auricles on the base of the leaf blades below, compound thyrses, staminate flowers with two completely fused stamens, and notably small, dry, woody fruits. Two of the three species occur in the area of the Guiana Shield, one endemic in Venezuela, the other one (D. yutajensis (Jabl.) Esser) mostly in Venezuela but reaching some mountains in the northern Brazilian Amazonia; the third species ( $D$. wurdackii Esser) is rare and endemic in a small area south of the Amazon River in Brazil. Dendrothrix is probably most closely related to Senefelderopsis; the latter is superficially quite similar, but differs in simple hairs, nectar glands on the upper side of the base of the leaf blade, staminate flowers with 3-5 free stamens, and unusually large, leathery-fleshy fruits; it is restricted to the Guiana Shield from Colombia to Guyana, but obviously not reaching Brazil (Esser 1995).

\section{Pleradenophora Esser}

A single Brazilian species, Sebastiania membranifolia Müll.Arg. from Central Brazil, cannot be grouped easily in any of the other Brazilian genera. It shares many-flowered staminate cymules with short-pedicellate flowers and fused sepals with Sapium or Stillingia, but the number of 3(-5) stamens per flower is shared with Gymnanthes. The basal leaf glands are quite unusual, situated in distinct basal auricles of the blade. Flowers and fruits are similar to Pleradenophora, a small genus described by Esser (2001) from Mesoamerica. Although the geographical distance is remarkable, the species might be related to that genus. This species is more widespread in Bolivia and Peru, and was aptly illustrated by Jablonski (1967b) under the illegitimate name of Sebastiania rhombifolia (Rusby) Jabl.

\section{Mabea Aubl.}

Because the German monograph of Esser (1994) is not available yet in another language and has not been published in a journal yet, some data of this thesis are provided here.

\section{Circumscription and taxonomy}

A complete revision was included in the thesis of Esser (1994). Recent partial local revisions were published by den Hollander \& Berg (1986) and Esser (1999d), and although quite short they, together, cover the majority of Amazonian taxa. Mabea is easy to recognize by the indumentum of reddish to brownish, dendritic hairs, the always and consistently, densely tomentose ovaries and fruits, the pistillate flowers with usually six sepal lobes (rarely three of them reduced to nearinvisibility, e.g. in M. anomala Müll.Arg.), the staminate flowers with usually five sepal lobes, and the enlarged stamen number (up to ca. 100 in M. pulcherrima Müll.Arg.). Except for the hair type (also shared with Dendrothrix), the other characters are globally unique in Hippomaneae and quite certainly autapomorphic. When these autapomorphies are subtracted, the genus appears very closely related to Gymnanthes (Esser 1994), which was also suggested by Wurdack et al. (2005). As discussed above, the Mabeinae of Pax \& Hoffmann (1912) were very likely polyphyletic, based on stamen number and inflorescence branching only that can well be homoplastic, known also from other paleotropical genera. Mabea and Gymnanthes share, however, leaf margin, venation, marginal glands, the staminate flowers (that can be extremely similar in some species except for the sepal number), and the fruits and seeds than can only be distinguished by indumentums and sepal number, but hardly by any other character.

Mabea has 40 currently accepted species according to Esser (1993b, 1994). One Mexican species, Mabea tenorioi Mart.Gord., J.Jiménez Ram. \& Cruz Durán, has been described since then, but three of the new species discussed by Esser (1994), from Venezuela, have not been fomally published yet. The species-level taxonomy, based on the revision of Esser, was incorporated in the World Checklist of Euphorbiaceae (Esser 2000). In the meantime, seven additional undescribed species have been found, with three of these from Brazilian Amazonia (the other ones from Bolivia, Colombia, Peru, Venezuela, and Guyana). The description of all novelties is in preparation (Esser, ined.). The overall species number of Mabea will then be around 50. Mabea is therefore the largest genus of the whole tribe. From these species, 24 can be found in Brazil (including the still undescribed ones), with eight of them endemic. The endemic taxa grow in Bahia (one) or Amazonia (remaining ones).

The stamen number, much used by Pax \& Hoffmann (1912) and Jablonski (1967a) for the distinction of species, is very variable within species but with much overlap between species, and is not useful for species delimitation. Species can usually be separated by details of the pubescence, leaf glands, venation, and fruit size, sometimes also 
by characters of the pistillate flowers and staminate bracts. With the exception of a group of species of Andean montane forests, species of Mabea can be distinguished by leaf characters alone.

Two names were misapplied quite often in herbaria and publications: Mabea occidentalis Benth. is a widespread species from Mexico to northern South America, but it does not occur in Brazil; M. caudata Pax \& K.Hoffm. is a synonym of the Amazonian Mabea speciosa Müll.Arg., but determinations as such are mostly misidentifications such as by Barros et al. (1982), who studied a plant determined as M. caudata, but which was in fact $M$. nitida Spruce ex Benth. The name Mabea piriri Aubl. was understood by Esser $(1994,2001)$ in a wide sense, ignoring differences in the size of the inflorescence, and therefore the species is now the most widespread one, ranging from Colombia and Peru through the whole of Amazonia to the Atlantic Coastal Forest.

\section{Pollination and palynology}

Mabea has a number of unusual floral characters: the inflorescences are pending, often on a long peduncle, and often with dull-reddishbrownish colours; the nectar glands at the base of the floral bracts are large and produce copious nectar; the style of the pistillate flowers is often conspicuously long, up to $33 \mathrm{~mm}$ (M. standleyi Steyerm.); the pedicels of all flowers are long, and the stamen number often is enlarged to up to ca. 100 (M. pulcherrima Müll.Arg.) with the filaments reduced at the same time (sessile anthers). Therefore inflorescences of a penicillate syndrome are present, with a diameter of up to $12 \mathrm{~cm}$ (Mabea pulcherrima) or only $5 \mathrm{~mm}$ (M. anomala Müll. Arg.). This is correlated with pollination. Species of Mabea are visited by a wide range of animals, and the species studied so far are obviously pollinated by bats, diurnal or nocturnal mammals, and Psittacid birds, as was described for Panama by Steiner (1983), and for Brazil by, among others, Vieira et al. (1991), Vieira \& Carvalho-Okano (2007), Da Silva (2008). Mabea is the only genus of Euphorbiaceae showing this pollination syndrome, perhaps besides Hura with only two species.

On the other hand, not all species of Mabea show this syndrome. Two Amazonian species ( $M$. anadena Pax \& K.Hoffm. with pubescent leaves, M. nitida with glabrous leaves) have eglandular floral bracts, and the filaments of the ca. 10-20 stamens are long, exposing the anthers. Some other species seem to be intermediary, such as the Andean M. macbridei I.M.Johnst. with much reduced glands of the bracts but with only short filaments; in M. pohliana (Benth.) Müll.Arg., the stamen number is reduced to only 3-4, although bract glands are present. These species all have yellowish-green inflorescences without any red, and the inflorescences are richly branched with only short peduncles, the single branches with a diameter of less than $20 \mathrm{~mm}$; this is in contrast to most of the other species, which usually unbranched thyrses of mostly more than $20 \mathrm{~mm}$ diameter, and with very often reddish-brownish colours. These species are possibly anemophilous or entomophilous; $M$. nitida at least is a species of riverine and gallery forests, so that the trees are quite exposed, whereas $M$. anadena grows in primary rain forests. Mabea therefore seems to be one of the very few genera of flowering plants that shows both a chiropterophilous and an entomophilous syndrome in different species within the same genus; other examples would be, u.a., Parkia R.Br. (Hopkins 1984). This is also paralleled by pollen characters. Bat-pollinated plants tend to have larger pollen grains than plants pollinated by other means (Stroo 2000). Several species of Mabea have notably large pollen grains. Hippomaneae, except for Rhodothyrsus (and with a few genera not studied yet) have quite homogeneous pollen grains ("Hippomane type" the "Hippomane configuration" fide Punt (1962), tricolporate with the polar axis ca. 30-40 $\mu \mathrm{m}$ long and small tectum perforations). Pollen grains of Mabea are of the same basic type but ca. 35-70 $\mu \mathrm{m}$ long, including possibly the largest ones found in Hippomanae; within this variation, the largest grains are found in species with a typical penicillate syndrome, whereas $M$. nitida is among the species with the smallest grains of ca. $35 \mu \mathrm{m}$. The pollen of $M$. nitida also seems to be notably less sticky, often found scattered on herbarium sheets. Within the genus Esser (1994) also found differences in the size of the tectum perforations, which are in some species (e.g., $M$. standleyi Steyerm., a typical 'penicillate' species) larger than in other typical Hippomaneae, although still smaller than in Rhodothyrsus. Although the pollen variation within Mabea is exceptional in Hippomaneae, the genus does not show any known diagnostical, palynological character. A more detailed palynological study would certainly yield interesting results. 


\section{Subdivision}

Pax \& Hoffmann (1912) distinguished four sections in Mabea. This could not be confirmed (Esser 1994). The species can be separated into two morphological groups:

A. Mabea sect. Spiculigerae Pax \& K.Hoffm.

Leaves with a small apical awn, lower surface papillate completely or near the stomata only (Herbert 1897). Sepals of mature pistillate flowers valvate. Staminate cymules consisting of five flowers with mostly connate pedicels, the pedicels without a distinct articulation. Lectotype (proposed here): M. fistulifera Mart. Additional species. Mabea angustifolia Spruce ex Benth.

This section is very probably monophyletic. It includes only two species, identical with the four names of Pax \& Hoffmann (1912), two of which being synonyms now. It is also identical with the unnamed Section 1 of Müller (1866). The species are typical elements of Central Brazil (Cerrado), where they overlap, and in secondary vegetation; both have inflorescences with typical penicillate syndrome and dull-reddish-brownish colours.

\section{B. Mabea sect. Mabea}

Leaves without a small apical awn, lower surface not papillate. Sepals of mature pistillate flowers imbricate. Staminate cymules consisting of one or three (rarely irregularly more but never five) flowers with their pedicels free or only slightly connate at base, with a distinct articulation each. Type: M. piriri Aubl. All remaining species.

Section Mabea here includes three remaining sections of Pax \& Hoffmann, sect. Apodae Pax \& K.Hoffm., sect. Intermediae Pax \& K.Hoffm., sect. Umbelluliferae Pax \& K.Hoffm., nom. inval. (including the type of the genus, M. piriri Aubl.). These sections, formerly separated by differences in nectar glands of the pistillate calyx and branching patterns of the inflorescence, are all connected by intermediate taxa, and their distinction was certainly artificial. Sect. Mabea in this wide sense also agrees with the unnamed Section 2 of Müller (1866). No phylogenetic subdivision of sect. Mabea is obvious so far, even the monophyly is unproven. The species included show a wide ecological amplitude, but are poorly represented in Central Brazil.

\section{Biogeography}

Obviously closely related pair of species often show an allopatric distribution pattern (e.g, M. occidentalis and M. piriri; M. montana Müll. Arg. and M. taquari Aubl.). Therefore the actual species number in a given region is often not very high. The highest species diversity is found in the Guayana Highlands, in particular in the area of the Pakaraima Mountains, with a number of very local endemics. Also in Amazonia, there are several endemics, many of them being species of white sand vegetation. Few of the more widespread species have an Amazonian distribution, such as M. pulcherrima Müll.Arg.; this species is the only liana in the genus (and presumably the only one in the Hippomaneae), although several species tend to have a spreading to somewhat climbing growth.

The two species reaching the northern limit of the genus in Mexico on the Tropic of Cancer ( $M$. occidentalis) and its southern limit in São Paulo state of Brazil on the Tropic of Capricorn (M. piriri, formerly called Mabea brasiliensis Müll.Arg. but synonymized by Esser 1994, 2001) are very similar and obviously closely related, so that the wide geographical distribution of Mabea is probably more recent, reached by dispersal.

\section{Gymnanthes Sw.}

This genus had been treated under the name Ateramnus P.Browne (1756) by several authors in the past. Ateramnus would have nomenclatural priority over Gymnanthes Swartz (1788). Ateramnus was published with a very short and not very decisive protologue, and no original material is known. Any interpretation of the name is very tentative at this moment, and there does not seem to be any clear indication that the two names should be treated as congeneric. The situation has been discussed by Webster (1983) and Kruijt \& Zijlstra (1989) who came to different conclusions, as a synonym of Sapium or as a possible senior synonym of Gymnanthes. The arguments to change all names of Gymnanthes to Ateramnus do not appear to be very conclusive. Currently the name Ateramnus is not in use, although it was taken up by Oe (1983) in her Dutch MSc thesis, which was intended as a revision of Gymnanthes but was in fact very incomplete.

Another possible nomenclatural problem including Gymnanthes is Gussonia Sprengel (1821), currently treated as junior synonym of Gymnanthes; it is discussed under Actinostemon below.

Gymnanthes had been treated by Pax \& Hoffmann (1912) and Webster (1994) in a narrow sense, uniting species with a reduced staminate calyx and numerous stamens per flower. Esser (1994, 1999b, 2001; Esser et al. 1998, 2010) applied 
a wider concept. The reasoning was that these few characters of the staminate flowers should be considered as synapomorphic for few species only, whereas in most other characters these species of Gymnanthes s. str. obviously agree with Adenogyne Klotzsch and Sarothrostachys Klotzsch - which were united as separate sections with Sebastiania by Pax \& Hoffmann and Webster. Therefore the two genera of Klotzsch (1841) should probably be united with Gymnanthes.

Esser et al. $(1998,2010)$ discussed that, in addition to these potential nomenclatural problems, there are paleotropical genera such as Shirakiopsis Esser that are quite similar to Gymnanthes in several characters. On the other hand, few neotropical species such as G. hypoleuca Benth. and $G$. discolor differ by entire leaves with laminar leaf glands closer to the lamina midrib. According to Wurdack et al. (2005), Gymnanthes in this wide sense might not be completely monophyletic. The majority of the species certainly forms a clade (also supported by Wurdack et al. (2005); his 'Sebastiania klotzschiana' is a Gymnanthes), but G. hypoleuca Benth. and G. lucida Sw. are problematic. Further detailed studies are needed, including also some paleotropical taxa.

This expanded concept was already applied by Müller (1863), but not by Müller (1866) who obviously changed his mind between these publications. The genus is then pantropical and includes ca. 45 species (with several undescribed ones in particular from the Andean countries). The center of diversity is in Brazil. Many Brazilian species grow in drier forest types; the few species of the Old World tropics in African and Asia seem all to be restricted to primary moist forests. Several new combinations still need to be validated, but should preferably been done so only after a careful revision of the species, which is still needed.

\section{Pseudosenefeldera Esser}

The monotypic genus was first discussed and revised in the thesis of Esser (1994), and later validly published by Esser (2001).

Pseudosenefeldera is based on Senefeldera sect. Inclinatae Pax. The staminate flowers remain distinctly inclinate and zygomorphic even when mature, in contrast to Senefeldera. Table 2 summarizes differences between these and other genera that were formerly confused. Unique characters within the Hippomaneae are the peculiar bud structure (the enlarged basal bract of each side branch of the compound inflorescence initially covers the complete branch, later on the strongly zygomophic calyx of the always inclinate staminate flowers protects the stamens from one side), and the seeds with a dorsal chalaza. The genus is the only one besides Actinostemon that has deviating inflorescence buds, and the leaves can be very similar to that genus. The type collection of its single species, $P$. inclinata (Müll. Arg.) Esser (i.e., Spruce 3431 from Venezuela) was originally annotated as 'an Dactylostemon?'. In the molecular phylogeny of Wurdack et al. (2005) Pseudosenefeldera grouped together with A. amazonicus Pax \& K.Hoffm.

Pseudosenefeldera occurs in lowlands of the central and western Amazon region, but is completely absent from eastern Amazonia; it is common in particular in Peru on the lower Andean slopes. Usually growing in rain forests, the species can also be found on white sand vegetation, and the plants with smaller and more leathery leaves there had been separated as distinct species before, but should best be treated as local variation only (Esser 1994).

\section{Actinostemon Mart. ex Klotzsch}

A potential nomenclatural problem may be Gussonia (1821). Gussonia was doubtfully united with Gymnanthes (there treated as synonym of Excoecaria) by Jussieu (1824), but accepted as distinct genus by Klotzsch (1841). Since Müller (1866), its two species are usually treated under separate genera: Whereas G. concolor Spreng. is generally accepted as belonging to Actinostemon, being the basionym for A. concolor (Spreng.) Müll. Arg., the second species and type of the genus Gussonia, G. discolor Spreng., is currently treated as a species of Sebastiania (sensu Webster 1994) or Gymnanthes (sensu Esser 2001). This species is however unusual for Gymnanthes in having laminar leaf glands and needs careful study. Kuntze (1891) therefore united Gussonia with Actinostemon, in which case Gussonia would have priority over the latter.

Whereas Actinostemon and Gymnanthes had been considered as separate genera by most authors, they were united on few occasions, first discussed by Webster \& Huft (1989), Webster (1.c.) felt that "there appear to be no satisfactory distinguishing characters". While it is true that mature inflorescences of both genera can be very similar, they can be distinguished by at 
Table 2 - Differences between Senefeldera and the genera formerly confused with it (based partly on Table 1 of Esser (1998)).

\begin{tabular}{|c|c|c|c|c|}
\hline & Senefeldera & Rhodothyrsus & Pseudosenefeldera & Actinostemon \\
\hline Hair type & simple & $\begin{array}{l}\text { malpighiaceous- } \\
\text { dibrachiate \& simple }\end{array}$ & simple & simple \\
\hline Leaf arrangement & $\begin{array}{l} \pm \text { alternate below } \\
\text { but apically } \\
\text { pseudoverticillate }\end{array}$ & alternate & pseudoverticillate & $\begin{array}{c}\text { alternate to } \\
\text { pseudoverticillate }\end{array}$ \\
\hline Petiole pulvinate & not & distinctly & not & not \\
\hline $\begin{array}{l}\text { Enlarged glands } \\
\text { on leaf base }\end{array}$ & $\begin{array}{l}\text { distinct on } \\
\text { upper side }\end{array}$ & none & distinct near base below & $\begin{array}{c}\text { usually none, rarely } \\
\text { near base below }\end{array}$ \\
\hline $\begin{array}{l}\text { Additional glands } \\
\text { on leaf blade }\end{array}$ & laminar & $\begin{array}{l}\text { laminar, very } \\
\text { close to or even } \\
\text { touching midrib }\end{array}$ & laminar & laminar \\
\hline $\begin{array}{l}\text { Inflorescence } \\
\text { branching }\end{array}$ & 1-2-times & up to 5-times & 1-2-times & none [simple] \\
\hline $\begin{array}{l}\text { Protection of } \\
\text { flower buds }\end{array}$ & by large floral bracts & by large floral bracts & $\begin{array}{l}\text { by one enlarged bract } \\
\text { for whole branch, } \\
\text { additionally by }\end{array}$ & by sterile bud scales \\
\hline Mature staminate & & & zygomorphic calyx & \\
\hline $\begin{array}{l}\text { flowers zygomorphic- } \\
\text { inclinate }\end{array}$ & no & yes & yes & no \\
\hline Glands on floral bracts & large, distinct & small, hidden & absent & small to absent \\
\hline Inflorescence colour & yellowish-green & $\begin{array}{l}\text { (orange- to } \\
\text { purplish) red }\end{array}$ & yellowish-green & yellowish-green \\
\hline Pollen tectum & tectate-perforate & semi-tectate & tectate-perforate & tectate-perforate \\
\hline Seed coat & sculptured & sculptured & smooth & smooth \\
\hline Chalaza of seeds & basal & basal & dorsal & basal \\
\hline
\end{tabular}

least two quite important character complexes. First, Actinostemon always has entire leaves with laminar glands, distinctly remote from the blade margin; Gymnanthes, on the other hand, nearly always bears serrate to subentire leaves with strictly marginal glands ( $G$. discolor (Spreng.) Müll. Arg. and G. hypoleuca Benth. being exceptions here).Second, the floral buds are very different, and with the Hippomaneae primarily defined by the floral buds this is relevant: Gymnanthes has typical buds, with bracts of regular size which cover the young flowers; in Actinostemon, in contrast, the bracts are much reduced, and the inflorescence buds are covered and protected by a series of sterile bud scales ("scarious scales which enclose the very young flower-shoots", Bentham 1878: 244). These large and often striate bud scales are very obvious characters for Actinostemon, not found in any other genus. Therefore the opinion of Webster \& Huft (1989) and Webster (1994) is not followed here. Also the molecular data of Wurdack et al. (2005) place both genera clearly as separate. In addition, Pseudosenefeldera is more similar to Actinostemon than Gymnanthes in several characters, as discussed there.

Actinostemon is a neotropical genus with ca. 15 species, with the center of diversity in Brazil. All but one or two species grow in Brazil, and most have a restricted distribution in eastern Brazil. Unfortunately both revisions published in the last century, by Pax \& Hoffmann (1912) and Jablonski (1969), are very unsatisfactory. Unnatural species concepts were applied, relevant types not seen, and only few specimens were studied. Therefore plants of Actinostemon are often very difficult to name today, but not because the genus would be more complex than others. Actinostemon concolor 
(Spreng.) Müll.Arg. has recently been recorded from several other neotropical countries (Bolivia, Ecuador; Esser, ined.), and seems to be one of the most widespread species of Hippomaneae in the Americas.

\section{Senefeldera Mart.}

Senefeldera, although initially described from a single species only, became a very unnatural genus later. Several authors described or combined species in Senefeldera sharing compound thyrses with more than 3 stamens per flowers, a neotropical distribution, and being not Mabea; but some of these species were quite different from the type of the genus in important characters. Senefeldera was accepted in this artificial circumscription by Pax \& Hoffmann (1912) and Webster (1994). Esser (1994) discussed this in detail. After removing Pseudosenefeldera and Rhodothyrsus, Senefeldera is now restricted to sect. Eusenefeldera Pax (nom. inval.) (Esser 1994, 2001). A complete revision of the genus in this strict sense was included by Esser (1994), although in German and not effectively published according to Art. 30.5 ICBN (Vienna Code). A formal publication is still pending.
The differences between Senefeldera and the genera recently separated from it are summarized in Table 2. Esser (1998) included a more detailed table listing 19 characters for distinction.

The plants of Senefeldera are trees of tropical lowland rain forests. The genus is characterized by entire and, at least apically, subverticillate leaves with one or two distinct nectar glands on the upper lamina base, a well-developed calyx of all flowers, usually compressed stigmas, 6 or more stamens per flower, and seeds with a rugulose testa. The genus has three species, which all are very similar superficially, even in many quantitative characters, but have sufficient differential characters. They all have a restricted distribution but are far apart from each other: One species [S. verticillata (Vell.) Croizat] is restricted to the environments of Rio de Janeiro, one species (S. triandra Pax \& K.Hoffm.) is rare in the southwestern Amazon (Brazil and Peru, not yet recorded for Bolivia), and the third species (S. testiculata Pittier) is only known from northwestern South-America (Venezuela to Panama). The following key to the three species gives some of the diagnostical differences:

1. Style present, $0.5-1.5 \mathrm{~mm}$ long; staminate flowers with a pedicel of ca. $1 \mathrm{~mm}$; laminar glands of the underside of the leaf blades situated inside the loops of the arching side veins S. verticillata

1'. Style absent (stigmas quite sessile); staminate flowers sessile or with a short pedicel of $<0.5 \mathrm{~mm}$; laminar glands of the underside of the leaf blades situated outside the loops of the arching side veins

2. Leaves and apical shoots pubescent, glabrescent......................................................... triandra

2'. Leaves and apical shoots glabrous S. testiculata

\section{Rhodothyrsus Esser}

The genus, which had been first discussed by Esser (1994), was published by Esser (1998). The type species, $R$. macrophyllus (Ducke) Esser, had been described under Senefeldera as S. macrophylla Ducke. Both genera are however sufficiently distinct (Tab. 2).

Rhodothyrsus is restricted to tropical rainforests, in contrast to most other genera of Hippomaneae; Rhodothyrsus macrophyllus grows in Amazonia from Peru to Brazil and the Guianas (but is absent from Venezuela), R. hirsutus Esser in northwestern Venezuela and the border area with Colombia, a poorly collected area. Rhodothyrsus macrophyllus has floral characters that are unique in Hippomaneae and even in Euphorbiaceae (Esser 1998). The inflorescences are much-branched and purplish-red, the strongly inclinate staminate flowers closely appressed to the central axis, with only one or few single flowers spreading at a given time and becoming available for pollinators. The pollen is also different from all other Hippomaneae studied so far, being semitectate with larger tectum perforations, so that Punt (1962) separated it into another pollen type. This syndrome could well be related to pollination by trap-lining insects, and pollination studies on this species would be desirable.

Rhodothyrsus is characterized by additional characters, such as malpighaceous-dibrachiate hairs, very long and apically pulvinate petioles (all unique in Hippomaneae), peculiar leaf glands always close to the midrib below and without conspicuous basal glands, and seeds with a distinctly ornamented testa. 


\section{Maprounea Aubl.}

Maprounea differs in several characters from the other Hippomaneae, such as the entire leaves with often enlarged glands at the lower base, staminate flowers congested into a small, nearly globular head but with the pistillate flowers large and separated, and the seeds with a distinctly foveolate testa in some but not all species, and with a very large caruncle covering a large part of the upper seed. The species-level taxonomy is sufficiently well established (Pax \& Hoffmann 1912; Esser 1999a and references cited therein). The genus is not only isolated in the characters mentioned above, but is also remarkable as an amphi-Atlantic genus with a comparable species diversity on both sides of the Atlantic Ocean, with two species in tropical Africa, and three species in tropical South-America. This would be the only such example in the tribe except for possibly Sebastiania/Excoecaria (as a united genus).

All three neotropical species occur in Brazil and are often very common. Maprounea guianensis Aubl. has a very wide distribution from Panama to Bolivia, the other two taxa are somewhat more restricted, M. amazonica Esser n Amazonian floodplain forests, and M. brasiliensis A.St.-Hil. in drier Cerrado vegetation. Although small, Maprounea is of some interest for the phylogeny and biogeography of the tribe.

\section{Conclusions}

The tribe Hippomaneae in Brazil is well circumscribed morphologically, although very probably not monophyletic in its previous circumscription. Nearly all genera accepted here, following Esser (1994, 2001) are presumably monophyletic, as judged from a review of morphological characters in detail for Asia, but also including several neotropical genera relevant for nomenclature (Esser et al. 1998; Welzen \& Esser 1998), and in a less detailed review of all 33 worldwide genera of the tribe in a phylogenetic context (Esser 1994, 2001).

Several genera occurring in Brazil have recent and published complete taxonomic revisions: Dendrothrix, Maprounea, Rhodothyrsus, Sapium, Stillingia. For other Brazilian genera, a revision was done but has not been published yet in a journal: Mabea, Sebastiania, Senefeldera, Pseudosenefeldera. The genera without an available revision are Actinostemon, Microstachys (currently in preparation), and Gymnanthes. A better understanding of Gymnanthes (one of the very few genera possibly not monophyletic) is needed, but because of the complexity of the nomenclatural and taxonomic problems involved, it should include taxa from outside of Brazil and even the Paleotropics.

The species inventory of Hippomaneae is more advanced in Brazil than in many other Neotropical countries, so that very few undescribed species are known (mostly in Mabea). Many species do not seem to be threatened at this moment, as the Hippomanae do not include a large number of local endemics (unlike, e.g., Croton), but some genera do include a number of endemics in Brazil, particulary in Actinostemon (Bahia, Rio de Janeiro etc.), Microstachys (Bahia, Minas Gerais), Mabea (Amazonia), and Stillingia (NE Brazil).

Problems with the generic circumscription and pending nomenclatural problems remain in particular in Gymnanthes and Sebastiania, both including paleotropical names that cannot be solved with the Brazilian taxa alone.

\section{Acknowledgments}

Data for this publication were obtained over several years at different institutions I could work with, and funded from various sources. I need to thank the staff and colleagues of the Herbarium Hamburgense, Germany (HBG), the National Herbarium of the Netherlands, Leiden branch, Netherlands (L), the late herbarium of Utrecht University, Netherlands (U), the Harvard University Herbaria, Cambridge (A, GH), and the Botanische Staatssammlung München, Germany (M) for manyfold support. Specimens studied for various projects were received from numerous herbaria on loan and during visits, that cannot be listed here in detail. My thanks are also due to Ricardo Secco and Anna Ilkiu Borges who initiated this publication, and two anonymous reviewers for their helpful comments.

\section{References}

Agardh, J.G. 1858. Theoria Systematis Plantarum. Gleerup, Lund. 404p., 28 pl.

APG III - Angiosperm Phylogeny Group. 2009. An update of the Angiosperm Phylogeny Group classification for the orders and families of flowering plants. Botanical Journal of the Linnean Society 161: 105-121.

Baillon, H.E. 1858. Étude générale du groupe des Euphorbiacées. Masson, Paris. 684p., 27 pl.

Baillon, H.E. 1874. Euphorbiacées. Histoire des Plantes 5: 105-256. Hachette, Paris. 
Balakrishnan, N.P. \& Chakrabarty, T. 2007. The family Euphorbiaceae in India. Bishen Singh Mahendra Pal Singh, Dehra Dun. 500p.

Barros, D.A.D.; Alvarenga, M.A. de; Gottlieb, O.R. \& Gottlieb, H.E. 1982. Naringenin coumaroglycosides from Mabea caudata. Phytochemistry 21:2107-2109.

Belgrano, M.J. \& Pozner, R. 2005. Stillingia yungasensis (Euphorbiaceae): a new species from Northwestern Argentina and Southern Bolivia. Systematic Botany 30: 134-138.

Bentham, G. 1878. Notes on Euphorbiaceae. Journal of the Linnaen Society, Botany 17: 185-267.

Bentham, G. \& Hooker, J.D. 1880. Euphorbiaceae. In: Bentham, G. \& Hooker, J.D. (eds.). Genera plantarum ad exemplaria imprimis in herbariis kewensibus servata definita 3(1). Reeve \& Co., London. Pp. 239-340, 448.

Browne, P. 1756. Civil and Natural History of Jamaica in three Parts. Printed for the author, and sold by T. Osborne and J. Shipton, London.

Bruyns, P.V.; Mapaya, R. \& Hedderson, T. 2006. A new subgeneric classification for Euphorbia (Euphorbiaceae) based on molecular data. Taxon 55: 397-420.

Da Silva, P.S. 2008. Parakeets (Aratinga aurea and Brotogeris chiriri, Psittacidae) as potentials pollinators of Mabea fistulifera Mart. (Euphorbiaceae). Revista Brasileira de Ornitologia 16: 23-28.

den Hollander, G. \& Berg, C.C. 1986. Studies on the flora of the Guianas 21: Mabea species (Euphorbiaceae) of the Guianas - a precursor. Proceedings of the Koninklijke Nederlandse Akademie van Wetenschappen, Series C 89: 147-157.

Dumortier, B.C.J. 1829. Analyse des familles des plantes, avec l'indication des principaux genres qui s'y rattachent. Casterman, Tournay. 104p.

Esser, H.-J. 1993a. Dendrothrix, a new generic concept in neotropical Euphorbiaceae. Novon 3: 245-251.

Esser, H.-J. 1993. New species and a new combination in Mabea Aublet (Euphorbiaceae) from South America. Novon 3: 341-351.

Esser, H.-J. 1994. Systematische Studien an den Hippomaneae Adr. Jussieu ex Bartling (Euphorbiaceae), insbesondere den Mabeinae Pax \& K. Hoffm. Doctoral Dissertation, Universität Hamburg. 305 p., 36 pl.

Esser, H.-J. 1995. A taxonomic revision of Senefelderopsis Steyerm. (Euphorbiaceae), including additional notes on Dendrothrix Esser. Mitteilungen des Instituts für Allgemeine Botanik Hamburg 25: 121-133.

Esser, H.-J. 1998. New combinations in Microstachys (Euphorbiaceae). Kew Bulletin 53: 955-960.

Esser, H.-J. 1999a. Taxonomic notes on Neotropical Maprounea (Euphorbiaceae). Novon 9: 32-35.
Esser, H.-J. 1999b. A partial revision of the Hippomaneae (Euphorbiaceae) in Malesia. Blumea 44: 149-215.

Esser, H.-J. 1999c. Rhodothyrsus, a new genus of Euphorbiaceae from tropical South-America. Brittonia 51: 170-180.

Esser, H.-J. 1999d. Dendrothrix, Mabea, Sapium, Senefelderopsis. In: Berry, B.; Yatskievych, K. \& Holst, B. (eds.). Flora of the Venezuelan Guayana. Vol. 5. Missouri Botanical Garden Press, St. Louis. Pp. 139-141, 163-171, 218-221, 224-225.

Esser, H.-J. 2000. Various genera of Hippomaneae. In: Govaerts, R; Frodin, D.G. \& Radcliffe-Smith, A. World checklist and bibliography of Euphorbiaceae (with Pandaceae). Royal Botanic Gardens, Kew.

Esser, H.-J. 2001. Tribes Hippomaneae, Hureae, Pachystromateae. In: Radcliffe-Smith, A. Genera Euphorbiacearum. Royal Botanic Gardens, Kew. Pp. 352-397.

Esser, H.-J. 2002. A revision of Triadica Lour. (Euphorbiaceae). Harvard Papers in Botany 7: 17-21.

Esser, H.-J. 2010. A new combination in Stillingia (Euphorbiaceae) from Argentina and Bolivia. Novon 20: 147-148.

Esser, H.-J.; Berry, P.E. \& Riina, R. 2009. EuphORBia: a global inventory of the spurges. Blumea 54: 11-12.

Esser, H.-J.; Fátima de Araújo, M.F. \& Alves, M. 2010. A new species of Gymnanthes (Euphorbiaceae) from northeastern Brazil. Willdenowia 40: 345-349.

Esser, H.-J.; Welzen, P.C. van \& Djarwaningsih, T. 1998. A phylogenetic classification of Malesian Hippomaneae (Euphorbiaceae). Systematic Botany 22: 617-628.

Govaerts, R.; Frodin, D. \& Radcliffe-Smith, A. 2000. World checklist and bibliography of Euphorbiaceae (with Pandaceae). Royal Botanic Gardens, Kew. $1621 \mathrm{p}$.

Herbert, H. 1897. Anatomische Untersuchungen an Blatt und Axe der Hippomaneae. Inaugural dissertation, Munich. 62p.

Hopkins, H.C. 1984. Floral biology and pollination ecology of the neotropical species of Parkia. Journal of Ecology 72: 1-23.

Hurusawa. I. 1954. Eine nochmalige Durchsicht des herkömmlichen Systems der Euphorbiacaeae im weiteren Sinne. Journal of the Faculty of Science, University of Tokyo, Section 3, Botany 6: 211-341.

Jablonski, E. 1967a. Euphorbiaceae. In: Maguire, B. (ed.). Botany of the Guayana Highlands VII. Memoirs of the New York Botanical Garden 17: 80-190.

Jablonski, E. 1967b. Notes on Neotropical Euphorbiaceae. 2. New species and transfers. Phytologia 14: 450-456.

Jablonski, E. 1969. Notes on neotropical Euphorbiaceae. 4. Monograph of the genus Actinostemon. Phytologia 18: 213-240. 
Jussieu, A.L. 1824. De Euphorbiacearum generibus medicibusque earundem viribus tentamen. Didot, Paris. $118 \mathrm{p} ., 18 \mathrm{pl}$.

Klotzsch, J.F. 1841. Neue und weniger gekannte südamerikanische Euphorbiaceen-Gattungen. Archiv für Naturgeschichte 7: 175-209, pl. VII-IX.

Kruijt, R.C. 1996. A taxonomic monograph of Sapium Jacq., Anomostachys (Baill.) Hurus., Duvigneaudia J. Léonard and Sclerocroton Hochst. (Euphorbiaceae tribe Hippomaneae). Bibliotheca Botanica 146: 1-109.

Kruijt, R.C. \& Zijlstra, G. 1989. Proposal to conserve 4483 Sapium Jacquin, 1760 against Sapium P. Browne, 1756 (Euphorbiaceae). Taxon 38: 320-325.

Kuntze, O. 1891. Revisio generum plantarum. A.Felix, Leipzig.

Linnaeus, C. 1753. Species Plantarum. Laurentii Salvi, Stockholm. 1200p.

Melo, A.L. de. 2005. Revisão de Sebastiania Spreng. sensu stricto (Euphorbiaceae-Hippomaneae). Universidade Federal Rural de Pernambuco. 117p.

McVaugh, R. 1995. Euphorbiacearum sertum NovoGalicianarum revisarum. Contributions of the University of Michigan Herbarium 20: 173-215.

Müller. J. 1863. Euphorbiaceae. Vorläufige Mitteilungen aus dem für De Candolle's Prodromus bestimmten Manuscript über diese Familie. Linnaea 32: 1-126.

Müller, J. 1866. Euphorbiaceae excl. Euphorbieae. In: DeCandolle, A. Prodromus systematis naturalis regni vegetabilis 15(2). Masson, Paris. Pp. 189-1286.

Oe, E. 1988. Een revisie van Ateramnus. MSc. thesis. University of Utrecht. 47p.

Pax, F. \& Hoffmann, K. 1912. EuphorbiaceaeHippomaneae. In: Engler A. (ed.). Das Pflanzenreich IV.147.v (Heft 52). Engelmann, Leipzig. 319p.

Punt, W. 1962. Pollen morphology of the Euphorbiaceae with special reference to taxonomy. Wentia 7: 1-116.

Radcliffe-Smith, A. 2001. Genera Euphorbiacearum. Royal Botanic Gardens, Kew. 455p.

Riina, R. \& Berry, P.E. (coordinators). 2011. Euphorbia planetary biodiversity inventory database. Available in $<$ http://app.tolkin.org/projects/72>. Access on 14 Oct 2011.

Rogers, D.J. 1951. A revision of Stillingia in the New World. Annals of the Missouri Botanical Garden 38: 207-259.
Silva, M.J. \& Esser, H.-J. 2011. Two new taxa and two new combinations in Microstachys (Euphorbiaceae). Phytotaxa 32: 18-26.

Sprengel, C.P.J. 1821. Neue Entdeckungen im ganzen Umfang der Pflanzenkunde. Fleischer, Leipzig.

Steiner, K.E. 1983. Pollination of Mabea occidentalis (Euphorbiaceae) in Panama. Systematic Botany 8: 105-117.

Steinmann, V.W. \& Porter, J.M. 2002. Phylogenetic relationships in Euphorbiaeae (Euphorbiaceae) based on ITS and ndhF sequence data. Annals of the Missouri Botanical Garden 89: 453-490.

Stroo, A. 2000. Pollen morphological evolution in bat pollinated plants. Plant Systematics and Evolution 222: 225-242.

Swartz, O.P. 1788. Nova genera \& species plantarum: seu Prodromus descriptionum vegetabilium, maximam partem incognitorum quæ sub itinere in Indiam Occidentalem annis 1783-87 digessit Olof Swartz. M. Swederi, [Stock] holm et al.

Vieira, M.F. \& Carvalho-Okano, R.M. 2007. Pollination biology of Mabea fistulifera (Euphorbiaceae) in South-Eastern Brazil. Biotropica 28: 61-68.

Vieira, M.F.; Carvalho-Okano, R.M. \& Sazima, M. 1991. The common opossum, Didelphis marsupialis, as a pollinator of Mabea fistulifera (Euphorbiaceae). Ciência e Cultura 43: 390-393.

Webster, G.L. 1983. A botanical gordian knot : the case of Ateramnus and Gymnanthes (Euphorbiaceae). Taxon 32: 304-305.

Webster, G.L. 1994. Synopsis of the genera and suprageneric taxa of Euphorbiaceae. Annals of the Missouri Botanical Garden 81: 33-144.

Webster, G.L. \& Huft, M.J. 1989. Revised synopsis of Panamanian Euphorbiaceae. Annals of the Missouri Botanical Garden 75: 1087-1144.

Welzen, P.C. van \& Esser, H.-J. 1998. Phylogeny of the Malay species in the tribe Hippomaneae (Euphorbiaceae): added value for local floras. Acta Botanica Neerlandica 47: 261.

Wurdack, K.J.; Hoffmann, P. \& Chase, M.W. 2005. Molecular phylogenetic analysis of uniovulate Euphorbiaceae (Euphorbiaceae sensu stricto) using plastid rbcL and trnL-F DNA sequences. American Journal of Botany 92: 1397-1420. 